\title{
Studi Dampak Level Penetrasi Pembangkit Listrik Fotovoltaik pada Jaringan Distribusi
}

\author{
Septianissa Azzahra ${ }^{1}$; Ibnu Hajar²; Agus Yogianto $^{3}$ \\ 1, 2, ${ }^{3}$ Teknik Elektro, Sekolah Tinggi Teknik PLN \\ ${ }^{1}$ septianissa@sttpln.ac.id \\ 2ibnu.hjr@gmail.com \\ ${ }^{3}$ aayogi08@yahoo.com
}

\begin{abstract}
Recently distribution network have connected with power plant unit also with photovoltaic power plant. Therefore voltage profile of distribution grid not any more distance from source there is voltage drop but connected with photovoltaic power plant would be increase grid voltage in this connected point also in the grid line. In this study, the distribution grid with connected with photovoltaic power plant is modelled. By using through MATHLAB / SIMULINK, modeling and simulation can be done ondistribution grid with two point connected to the photovoltaic power plant. From the simulation and analysis obtained, that power injection to grid by photovoltaic power plant can affect voltage grid condition, but not affect grid frequency relatively. The grid voltage will increase if there is power injection to the connected point in grid. Increase the power penetration to the grid would be increase the rise voltage in the grid. The constraint in this case, that power penetration must be considered the condition of quality voltage because any trend for voltage wave become distorted.
\end{abstract}

Keywords: Photovoltaic Power Plant, Modelling. Simulation, Distribution Network, Voltage

\begin{abstract}
ABSTRAK
Jaringan distribusi saat ini sudah banyak yang terkoneksi dengan pembangkit listrik termasuk dengan pembangkit listrik fotovoltaik. Oleh sebab itu profil tegangan jaringan distribusi, tidak lagi semakin jauh dari sumber semakin turun tegangannya, tetapi adanya koneksi dengan pembangkit listrik fotovoltaik dapat menaikkan tegangan pada jaringan. Pada studi ini dimodelkan jaringan distribusi yang dikoneksikan dengan pembangkit listrik fotovoltaik. Melalui pemodelan MATHLAB/SIMULINK, telah dimodelkan jaringan distribusi yang dikoneksikan dengan pembangkit listrik fotovoltaik pada dua titik sambung di jaringan. Dari simulasi yang dilakukan, model jaringan ini menunjukkan bahwa koneksi pembangkit listrik fotovoltaik dengan injeksi daya tertentu mempengaruhi kondisi tegangan jaringan, tetapi relatif tidak mempengaruhi frekuensi di jaringan. Tegangan jaringan naik dengan adanya injeksi daya pada titik jaringan. Semakin besar penetrasi daya yang masuk ke jaringan, maka semakin besar kenaikan tegangan pada jaringan. Sekalipun demikian, penetrasi daya perlu memperhatikan kondisi kwalitas tegangan mengingat bentuk gelombang tegangan menjadi terdistorsi.
\end{abstract}

Kata kunci: Pembangkit listrik fotovoltaik, pemodelan, simulasi, jaringan distribusi, tegangan 


\section{PENDAHULUAN}

Penambahan kapasitas pembangkit listrik tenaga surya (PLTS) jenis fotovoltaik di Indonesia, saat ini akan semakin meningkat mulai dari kapasitas kecil sampai dengan kapasitas yang mencapai orde MegaWatt. Pada umumnya tenaga listrik dari pembangkit PLTS fotovoltaik saat ini masih dikoneksikan atau dihubungkan ke jaringan distribusi baik tegangan rendah maupun tegangan menengah. Pembangkit listrik tenaga surya berkapasitas menengah atau besar pada umumnya masih dipasang di daerah kepulauan atau daerah yang mempunyai lahan luas di luar perkotaan.

Sesuai dengan kebutuhan dan perkembangan regulasi, pada suatu saat di Indonesia akan banyak sebaran pembangkit tenaga surya fotovoltaik yang terpasang tidak hanya di daerah yang lahannya luas, tetapi juga di daerah perkotaan. Khusus untuk daerah perkotaan, bila pembangkit listrik dihasilkan dari-rumah-rumah penduduk, maka konsumen tidak bisa dipandang sebagai konsumen saja, tetapi juga dapat sebagai produsen tenaga listrik atau disebut sebagai prosumen. Hal ini tentunya membawa pengaruh kepada jaringan distribusi, karena selama ini jaringan distribusi hanya untuk dibebani, tetapi dengan adanya produsen tenaga listrik yang tersebar maka pada jaringan distribusi selain beban juga terdapat pembangkit-pembangkit listrik.

Studi sistem dengan perlakuan konvensional sudah tidak memadai lagi, apabila jaringan diperlakukan hanya sebagai jaringan distribusi dan beban, tetapi dibutuhkan studi analisa yang lebih detail yaitu analisa sistem jaringan distribusi tenaga listrik.

Oleh sebab itu untuk mengetahui kondisi profil tegangan pada jaringan distribusi, dengan adanya operasi pembangkit listrik fotovoltaik, dibutuhkan model jaringan yang dapat digunakan sebagai sarana untuk analisis dampak penetrasi pembangkit listrik fotovoltaik pada jaringan distribusi.

Dari studi oleh S Ali cs, telah dilakukan pemodelan jaringan distribusi di UK pada level rendah 400V dengan level penetrasi tinggi sampai dengan $100 \%$. Pembangkit listrik fotovoltaik dan beban dibuat model lumped tersebar pada sepanjang jaringan. Secara umum tegangan jaringan lebih tinggi pada iradians yang tinggi terutama pada penetrasi tinggi.

Dari studi integration of high level photovoltaic penetration of cluster, dilakukan inventarisasi dari permasalahan yang timbul dengan penetrasi tinggi antara lain terkait kestabilan sistem.

Dari studi maximum PV Plant penetration level on typical distribution feeder, oleh Anderson Hoke dari NREL,telah dicoba penetrasi PV pada berbagai tipe feeder dengan penetrasi sedikitnya 30 $\%$ dari beban feeder.

Pada penelitian ini yang dibuat adalah model jaringan distribusi yang terhubung dengan pembangkit listrik fotovoltaik.Sebagai dasar untuk melihat karakteristik kinerja pembangkit listrik, maka iradians dibuat bervariasi sesuai dengan penyinaran matahari harian.

Perkembangan di luar Indonesia, telah cukup lama para konsumen juga sebagai produsen listrik dengan pembangkit listrik fotovoltaik. Selain itu aturan di jaringan yang mengakomodir kebutuhan dan persyaratan pada sistem juga telah dibuat sebagai pedoman para pihak yang berkepentingan.

Regulasi yang mengatur konsumen tenaga listrik juga sebagai produsen tenaga listrik dengan pembangkit tenaga surya roof top (panel surya di atap rumah), saat ini sudah dikeluarkan Peraturan oleh kementrian ESDM dengan No.49 tanggal 18 Nopember 2018. Dengan keluarnya Permen ini, dalam waktu dekat ini diperkirakan pemakaian pembangkit listrik tenaga surya dapat berkembang untuk menunjang pertumbuhan pemakaian energi terbarukan.

Sebagai sumber daya pembangkit listrik, pada pembangkit listrik fotovoltaik yang digunakan adalah inverter sumber tegangan, karena sumber ini diharapkan mensuplai daya dengan tegangan konstan. Sebagai konverter sumber tegangan, dikenal perubahan daya tegangan searah ke tegangan 
bolak-balik dengan berbagai cara, yang pada dasarnya terkait dengan komutasi serta dengan switching tegangan.

Berkaitan denganpengoperasian pembangkit listrik energi terbarukan, khususnya pembangkit listrik yang bervariasi outputnya, maka level penetrasi pembangkit menjadi hal penting yang harus diperhatikan bagi pihak yang mengoperasikan dan mengatur jaringan tenaga listrik.

Level penetrasi diartikan sebagai perbandingan antara daya puncak pembangkit energi terbarukan dibagi dengan daya beban yang beroperasi pada suatu saat.

Secara umum level penetrasi dibagi menjadi tiga level yaitu :

- Level penetrasi rendah sampai dengan $30 \%$

- Level penetrasi menengah, 30 sampai dengan $50 \%$

- Level penetrasi tinggi, di atas $50 \%$.

Pada jaringan distribusi di US, pembangkit listrik fotovoltaik dengan penetrasi sampai dengan $15 \%$ pada saluran atau feeder tegangan menengah, biasanya tidak sampai menimbulkan dampak terhadap pengoperasian sistem distribusi, sehingga tidak diperlukan studi khusus untuk menangani dampak dengan terhubungnya pembangkit listrik fotovoltaik ke jaringan distribusi.

\section{METODE PENELITIAN}

\subsection{Pembuatan model}

Sebelum simulasi dilakukan, langkah awal adalah membuat model yang terdiri dari model pembangkit listrik fotovoltaik, model inverter yang lengkap beserta sistem kontrol serta model jaringan. Berdasarkan spesifikasi masing-masing bagian tersebut, maka dapat dibuat model jaringan dengan pembangkit listrik fotovoltaik sebagai berikut :

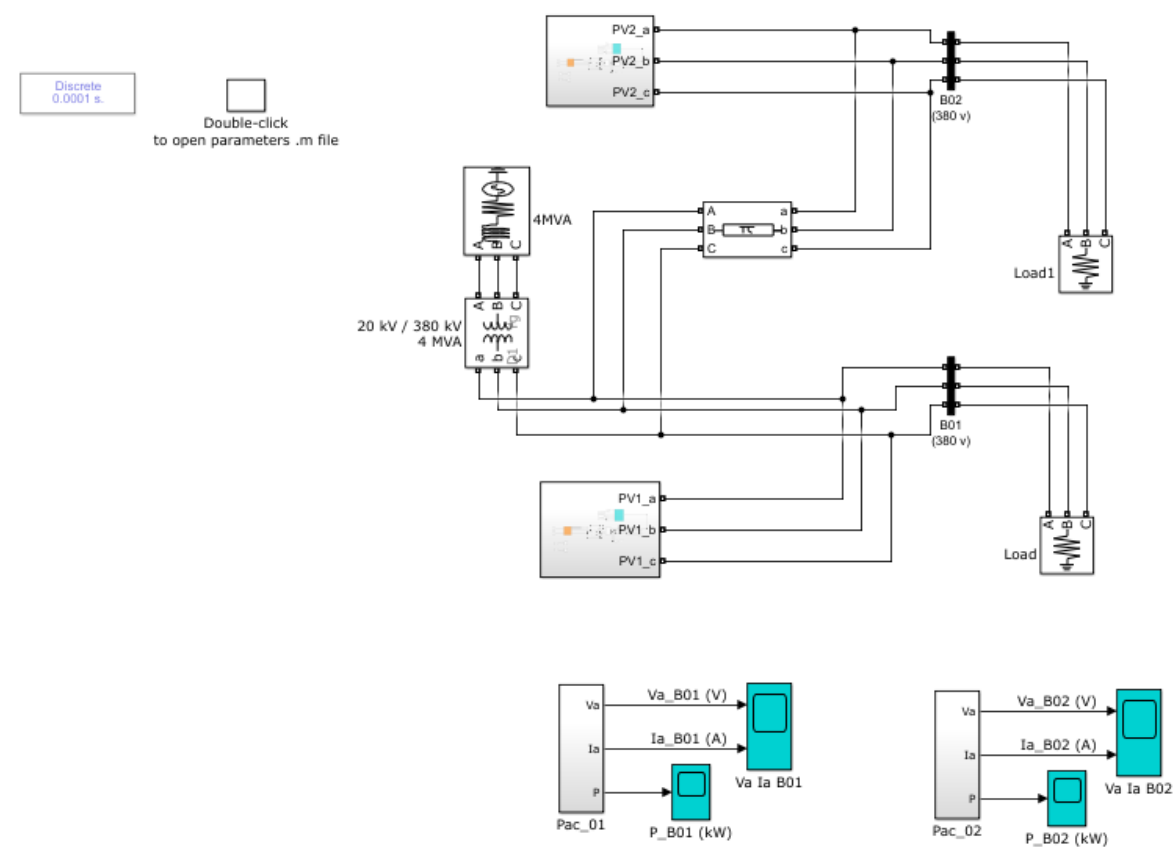

Gambar 1. Model jaringan distribusi koneksi dengan pembangkit listrik fotovoltaik 


\subsection{Prosedur Pengambilan Data}

Setelah diperoleh modellengkap jaringan dan pembangkit listrik fotovoltaik, maka model tersebut dijalankan (run)serta dilakukan simulasi.

Pertama-tama dilakukan pemeriksaan model dari pembangkit listrik fotovoltaik, dengan melihat keluaran tegangan dan daya yang dihasilkan pada mode iradiasi tetap dan suhu tetap.

Setelah dipastikan bahwa keluaran tegangan pembangkit listrik fotovoltaik / keluaran inverter sesuai dengan yang direncanakan, maka dilakukan simulasi operasi paralel dan pembebanan.

Selain itu pemeriksaan model juga dilakukan pada jaringan dengan terlebih dahulu menonaktifkan pembangkit listrik fotovoltaik. Setelah model beroperasi sesuai dengan rencana, maka pembangkit listrik fotovoltaik dihubungkan ke jaringan.

\section{HASIL DAN PEMBAHASAN}

Jaringan distribusi tegangan rendah $380 \mathrm{~V}$ dengan kapasitas daya 4 MVA terhubung pada pembangkit listrik fotovoltaik pada dua titik yaitu titik B01 dan titik B02.

Pada titik jaringan tersebut juga terhubung beban terbatas, sementara pembangkit listrik fotovoltaik divariasikan pada masing-masing kapasitas 2 x $100 \mathrm{~kW}, 2$ x $1000 \mathrm{~kW}$ dan 2 x $2500 \mathrm{~kW}$, masing-masing kapasitas tersebut merupakan representasi dari level penetrasi rendah, level penetrasi menengah dan level penetrasi tinggi.

Pada jaringan seperti gambar.1 dilakukan simulasi operasi jaringan tanpa koneksi dengan pembangkit tenaga surya fotovoltaik. Untuk mengetahui besarnya dan bentuk tegangan pada jaringan tersebut dilakukan pengukuran pada titik B01 dan B02. Kondisi tegangan pada operasi jaringan tanpa beban adalah seperti pada gambar 2 berikut :

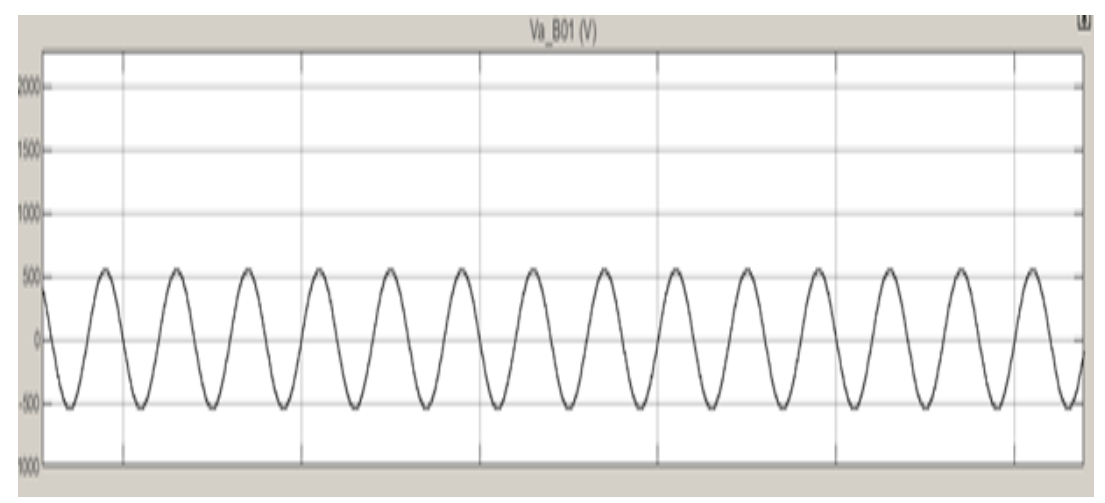

Gambar 2. Kondisi tegangan jaringan tanpa beban pada titik B01

Bila jaringan dibebani pada beban yang relatif kecil, maka diperoleh kondisi tegangan jaringan seperti pada gambar 3 berikut: 


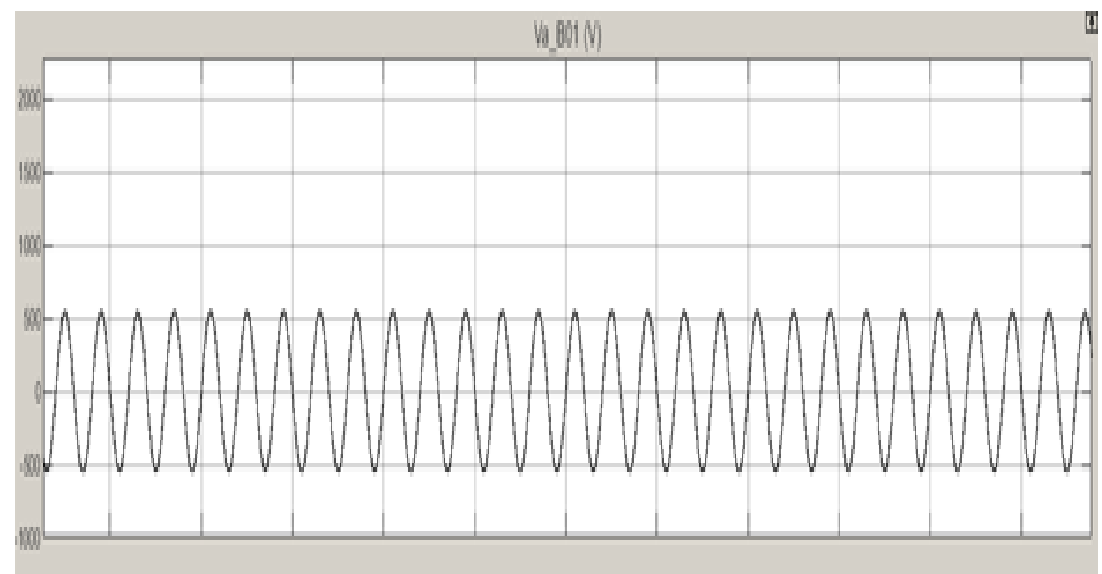

Gambar 3. Kondisi tegangan jaringan berbeban pada titik B01 tanpa koneksi PLTS

Dari gambar 2 dan gambar 3 dapat dilihat bahwa bentuk tegangan dapat dikatakan sama berbentuk sinusoidal dengan frekuensi $50 \mathrm{~Hz}$. Pada kondisi berbeban masih memenuhi persyaratan tegangan $+5 \%$ dan $-10 \%$.

Jaringan dengan koneksi pembangkit listrik fotovoltaik pada dua titik koneksi memperlihatkan bahwa tegangan di jaringan mengalami perubahan seperti pada gambar.4 berikut

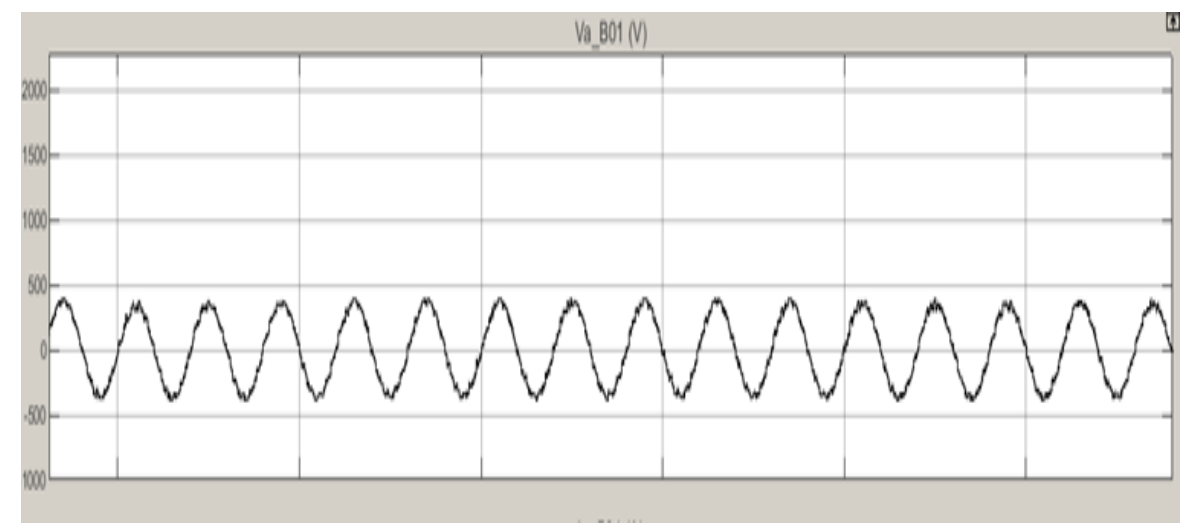

Gambar 4. Tegangan jaringan dengan koneksi PLTS

Pada koneksi dengan 2 kelompok pembangkit listrik fotovoltaik di 2 titik jaringan yang masingmasing berkapasitas $100 \mathrm{~kW}$, selain terjadi perubahan dari bentuk tegangan, juga terjadi perubahan besar tegangan yaitu menjadi lebih rendah. Perlu dicatat dalam hal ini, iradians dari sinar matahari masih pada kondisi iradians rendah $\left(30 \mathrm{~W} / \mathrm{m}^{2}\right)$, dengan demikian penetrasi daya masih relatif kecil, tetapi jaringan sudah terkoneksi dengan pembangkit listrik fotovoltaik, hal ini berpengaruh pada jaringan.

Kondisi tegangan di jaringan dengan koneksi pembangkit listrik fotovoltaik di dalam satu hari operasi mengalami perubahan karena :

1. Perubahan dari beban

2. Perubahan dari penetrasi pembangkit listrik fotovoltaik karena iradians yang berubah 
Oleh sebab itu karakteristik dari tegangan jaringan akan mempunyai profil tertentu seperti pada gambar 5 berikut:

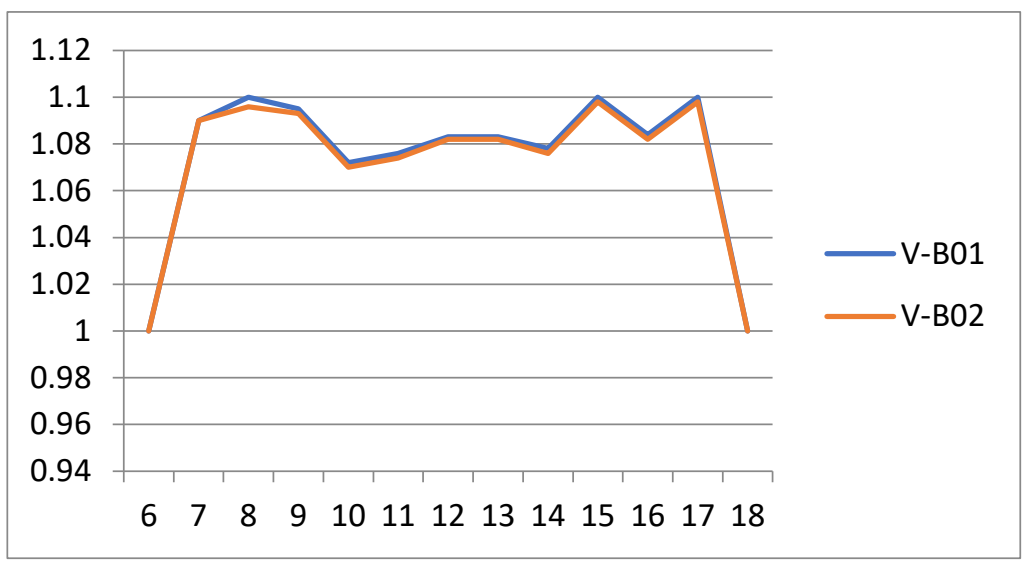

Gambar 5. Kondisi tegangan jaringan berbeban pada titik B01 dan B02 dengan koneksi 1 PLTS

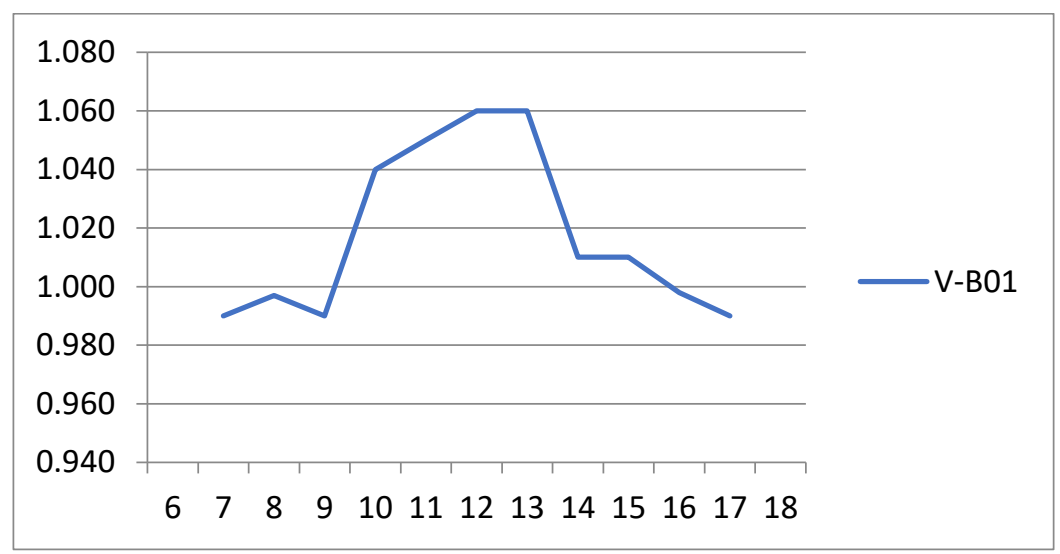

Gambar 6. Kondisi tegangan jaringan berbeban pada titik B01 dengan koneksi 2 PLTS

Dari profil tegangan pada gambar 6, dapat diketahui bahwa penambahan pembangkit listrik tenaga surya pada titik jaringan yang lain memperbaiki profil tegangan dibandingkan pada kondisi koneksi 1 PLTS seperti terlihat pada gambar 5. Batasan tegangan jaringan 1,05 p.u hanya terlampaui pada saat penyinaran maksimal yaitu antara jam 12 sampai dengan jam 13.

Pada penambahan daya PLTS di titik B01 dan B02, kapasitas daya pembangkit listrik surya ditambah, sehingga level penetrasi bertambah dari $33 \%$ menjadi $55 \%$ (level penetrasi tinggi). Pada masing-masing penetrasi tersebut, bentuk profil tegangan pada setiap jam hari penyinaran selain ada yang berkecenderungan sama, namun ada juga yang berbeda, seperti terlihat pada gambar berikut: 


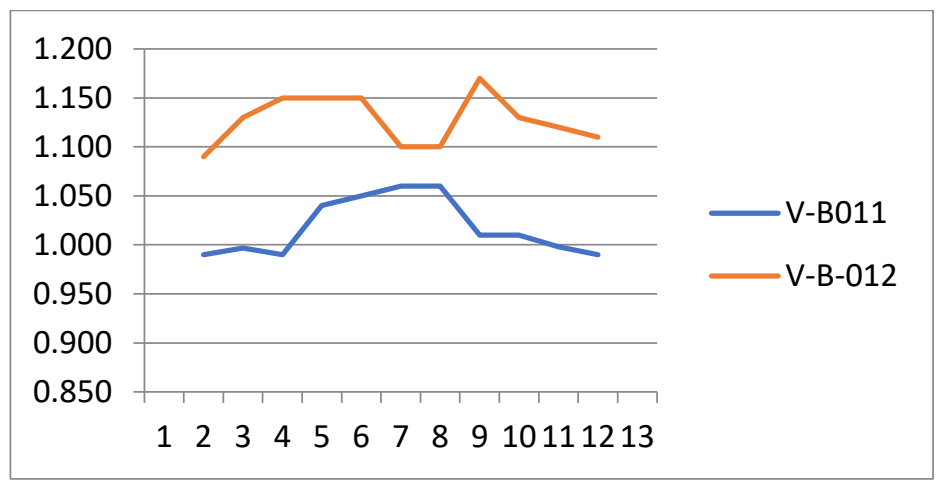

Gambar 7. Profil tegangan harian pada titik B01 pada penetrasi daya $33 \%(\mathrm{~V}-\mathrm{B} 011)$ dan $55 \%(\mathrm{~V}-\mathrm{B} 012)$

Secara umum dapat diketahui bahwa penambahan level penetrasi daya pada jaringan, meningkatkan besarnya tegangan pada jaringan. Pada penetrasi daya 55\% dapat dikatakan bahwa kondisi tegangan jaringan melebihi batasan operasi jaringan, sehingga membutuhkan pengaturan tegangan.

Bila hanya dari sisi kenaikan tegangan, maka peningkatan penetrasi daya ke jaringan terlihatmemberikan pengaruh positif, tetapi hal ini tidak cukup karena ada pertimbangan kwalitas tegangan yang perlu diperhatikan.

Penambahan daya pembangkit listrik fotovoltaik dengan penetrasi tinggi dapat mengubah bentuk gelombang tegangan seperti terlihat pada gambar 8 .

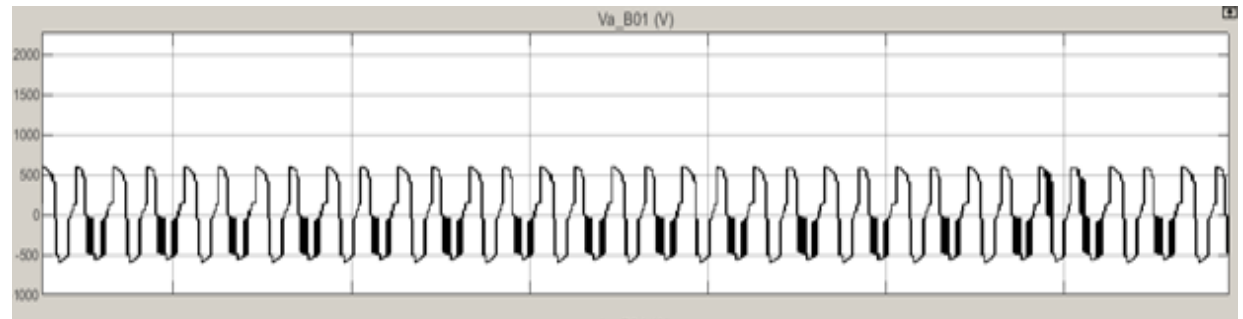

Gambar 8. Gelombang tegangan dengan koneksi fotovoltaik penetrasi tinggi

Besar tegangan dalam hal ini bertambah tetapi harmonisa juga menjadi bertambah besar sehingga ada batasan penetrasi pembangkit listrik fotovoltaik.

\section{KESIMPULAN}

Dari hasil pembahasan studi dampak level pada jaringan distribusi,maka dapat disimpulkan bahwa Pembangkit tenaga surya fotovoltaik dapat koneksi ke jaringan distribusi dan berfungsi sebagai sumber daya; Kondisi nilai tegangan pada jaringan distribusi dengan level penetrasi rendah menunjukkan hampir tidak terjadi perubahan tegangan jaringan; Profil tegangan pada jaringan distribusi dengan level penetrasi menengah dan level penetrasi tinggi, menunjukkan terjadi kenaikan tegangan pada setiap titik jaringan; Jaringan tanpa pengaturan tegangan mempunyai potensi terjadi kondisi tegangan lebih bila dikoneksikan dengan pembangkit listrik fotovoltaik; Penetrasi daya dari pembangkit listrik fotovoltaik perlu tetap memperhatikan kondisi jaringan, mengingat bahwa bentuk gelombang tegangan sinusoidal di jaringan menjadi terdistorsi. 


\section{DAFTAR PUSTAKA}

[1] Ali Keyhani, Marwali M, Min Dai. Integration of Green and Renewable Energy in Electric Power System. Wiley and Son, Inc. (2010).

[2] Anderson Hoke, Rebecca Butler. Maximum photovoltaic penetration levels on typical distribution feeder, NREL, July (2012).

[3] Farid K, Konrad M, Lisa D. Integration of photovoltaic power systems in high penetration clusters for distribution networks and minigrids. International Journal of Distributed Energy Resources Volume 3 No.3, July - September (2007).

[4] IEEE 1547.1.2015. Standard Conformance Test Procedures for equipment interconnecting Distributed resources with electric power systems.

[5] PT. PLN(Persero). Pedoman Penyambungan Pembangkit Listrik Energi Terbarukan ke sistem distribusi PLN.Keputusan Direksi PLN. (2014).

[6] PT. PLN(Persero). Power Quality (Regulasi harmonisa, Flicker dan ketidakseimbangan tegangan), SPLN D5.004-1. (2012).

[7] Permen ESDM RI No.49. Penggunaan sistem pembangkit listrik Tenaga surya atap oleh konsumen PT Perusahaan Listrik Negara (Persero), Nopember (2018).

[8] S Ali, N Pearsall, G Putrus. Impact of high penetration Level of Grid Connected Photovoltaic systems on the UK Low voltage distribution network. Northumbria University, UK. (2012). 